\title{
A Reappraisal of Energy Supply and Demand in 2050*
}

\author{
P.R. Bauquis ${ }^{1}$ \\ 1 Special Advisor to the Chairman, TotalFinaElf, 2, place de la Coupole, La Défense 6, 92078 Paris La Défense Cedex - France \\ e-mail: pierre-rene.bauquis@totalfinaelf.com
}

\begin{abstract}
* This paper was initially published in French in the magazine La Revue de l'énergie, No. 509, September 1999 (special issue for the 50th anniversary of the magazine). The original publication did not include the figures and graphs which have been incorporated in this new version, while the epilogue has been further developed.
\end{abstract}

\begin{abstract}
Résumé - Un point de vue sur les besoins et les approvisionnements en énergie à l'horizon 2050 Dans cet article, qui traite du bilan énergétique mondial à moyen terme (2020) et à long terme (2050), l'auteur s'est efforcé de présenter un scénario unique ayant, selon lui, la plus forte probabilité d'occurrence, contrairement aux approches habituelles de scénarios multiples. La seconde caractéristique importante de cet article est que l'accent n'est pas mis sur les incertitudes de la demande, mais sur les restrictions potentielles quant à l'offre d'énergies fossiles et, en particulier, de pétrole et de gaz. Les principales conclusions sont, qu'à l'horizon 2050, nous aurons besoin d'une forte croissance de l'énergie nucléaire mondiale, non seulement pour la production d'électricité, mais aussi en complément de l'industrie pétrolière, à laquelle elle fournirait à la fois des calories et de l'hydrogène sans émissions liées de $\mathrm{CO}_{2}$. Ces ressources d'hydrogène nucléaire devraient permettre de donner les fondements d'un développement durable à l'industrie pétrolière, ainsi qu'à l'industrie automobile, en fournissant des carburants de synthèse sur des bases économiquement et écologiquement satisfaisantes.
\end{abstract}

Mots-clés : approvisionnements énergétiques, demande énergétique, bilans énergétiques, réserves pétrolières, long terme, hydrogène, développement durable.

\begin{abstract}
A Reappraisal of Energy Supply and Demand in 2050 - In this paper dealing with the medium term (2020) and long term (2050) world energy mix the author has attempted to present a single most likely scenario, contrary to the usual multiple scenario approach. A second main characteristic is that the emphasis is not on the uncertainties of energy demand but on the potential limitations on the offer of fossil fuels and mainly of oil and gas. The main conclusions are that by 2050 we will need a large increase of the world nuclear industry, not only for the production of electricity but also to complement the oil industry, by providing it with necessary "CO $\mathrm{O}_{2}$ emissions free" heat and hydrogen. This nuclearbased hydrogen would allow to give a sustainable future to the oil industry, and to the automobile industry, by providing synthesis fuels on an economically and ecologically sound basis.

Keywords: energy supply, energy demand, energy mix, oil reserves, long term, hydrogen, sustainable development.
\end{abstract}




\section{INTRODUCTION}

There are a number of different energy scenarios currently being proposed, but most industry analysts forecast that world primary energy demand will approximately double by the year 2030, climbing from 9 to 18 Gtoe, and will roughly triple to 25 or 30 Gtoe by the year 2050. According to these projections, by 2050 fossil fuels will account for no more than two thirds of all energy consumed, as against $85 \%$ today.

The aim of this paper is to re-examine the assumptions underlying these energy forecasts covering the next halfcentury and reassess the world's likely energy equation in the year 2050. This may seem vain, because there is simply no way of predicting the likely impact of technological breakthroughs beyond 2010 or 2020, for example, or the fallout from any major economic or demographic upheavals. Furthermore-and this is probably the most important unknown factor in the equation - there is no way of knowing whether humankind will adopt more rational bases for determining fundamental social choices or whether the current irrational patterns in their multiple forms will continue to prevail. This factor will have a major impact on the world's energy future, and there is simply no way of predicting it. What is important is not the reality defined by scientists, but what people perceive and what they want. This is the very essence of democracy, and it is therefore a key factor for the future of the various energy sources. The whole debate about sustainable development and the ongoing environmental issues will be driven by our perceptions and desires, which will therefore play a key part in forging future energy trends. Whether or not we accept the risks involved in global warming, nuclear power and the use of individual transport will impact energy consumption over the next 50 years. And in the same way, whether or not we accept the risks involved in genetic engineering will determine-still over the coming 50 years-our response to the competing land-use requirements of food biomass and energy biomass.

The issues involved here are many, and this paper will restrict itself to a brief re-examination of the key parameters involved: economic growth, demographic developments, use of natural resources and particularly fossil fuels (oil, gas and coal), the outlook for renewable energies and the nuclear power issue. The aim here is to take a fresh look at the data and synthesize a new "energy equation for 2050" which may or may not be more accurate than those that have already been formulated. Contrary to usual practice, we will not present a variety of scenarios here but only what we perceive today as being the most likely future path.

\section{ECONOMIC GROWTH}

Over the last 20 years, we have seen a partial uncoupling of economic growth (as measured by growth in GNP) and energy consumption. This phenomenon is due partly to the "de-materialization" or "softening" of GNPs and partly to energy-saving measures, with industrial processes becoming increasingly energy-efficient and progress being made in the efficiency of heating and air-conditioning systems, lighting, household appliances and transport (automobile and aircraft engines, etc.). It is here that a second and opposing factor comes into play: with any increase in GNP comes a proportionally greater need/desire for transport and need/desire for comfort. This is particularly true in the case of emerging economies where the population aspires en masse to the way of life of a consumer society "as seen on (Western) TV". As it happens, these are the very countries that will generate the largest part of economic and demographic growth over the next half-century.

These aspirations to a "better" lifestyle may yet be curbed by ideological factors (extreme ecological movements, new ethical movements, a re-interpretation of the tenets of major religions), but such curbs are unlikely to have more than a minor impact on social aspirations fed by an increasingly global communication matrix. But to what extent do these comments apply beyond 2020? We simply do not know, and this is one of the major difficulties involved in making longterm predictions. We know how to extrapolate quite sophisticated mathematical models of existing trends, but any major shift in behavioral patterns renders such models inoperative.

\section{FUTURE DEMOGRAPHIC TRENDS}

One hardly needs to have a doctorate in demography to realize that 50 years ago Italian and Spanish women were having two or three times as many children as their German or Swedish counterparts, while the daughters of those same Italian and Spanish women today produce even fewer offspring than their Northern cousins. Only immigration can now keep the population levels in those two Latin countries stable.

This same kind of behavioral shift has been observed more recently in other countries of the Mediterranean rim such as Tunisia, Morocco, Turkey and Egypt, and the same trend is now manifesting itself very strongly in Algeria. There is no reason why this trend should not accelerate over the coming years and spread to other high-birth-rate zones (Fig. 1). The key factor affecting demographic growth is the rather mysterious phenomenon that we call the "desire to bear children". There is a strong cultural component in this desire, and at a time when cultural models are undergoing radical changes, birth rates can change very rapidly even without an equivalent change in religious attitudes. Cultural models are very strongly affected by the globalization of media content, with satellites now beaming into the most remote global villages the image of an "ideal family" heavily 


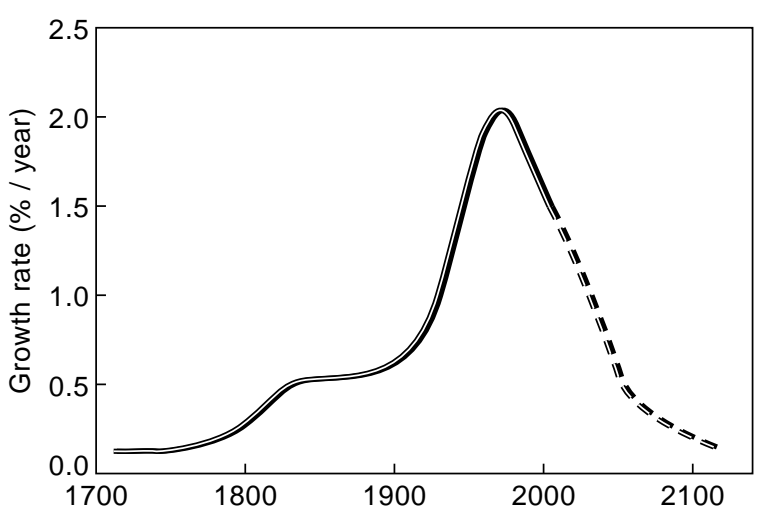

Figure 1

Growth rate evolution of the world population.

influenced by North American and European canons. Over the next 20 or 30 years, the "norms" conveyed by television will be reinforced by further cultural Westernization via the Internet. With further development of solar photovoltaic power, it is a good bet that even before 2020 the average Touareg tent and Mongol yurt will boast satellite TV, cell phones and Internet access to boot.

Demography is right at the heart of the long-term world energy demand picture, and as such it requires a clear stance: on the basis of the factors outlined above, by 2050, world population is more likely to stand at 8 billion people (+/ 2 bn) than at the 10 billion (+/ $1 \mathrm{bn})$ that is usually predicted. This means that in our view the world population is no more likely to reach 10 billion in 2050 than it is to come back to the present level of 6 billion.

\section{THE QUESTION OF FOSSIL FUEL RESOURCES AND RESERVES [1-5]}

We will deal with this aspect of the energy outlook in some detail as, in our opinion, the constraints on the future potential supply of the various energies are underestimated by most studies dealing with this subject.

It is presently fashionable to say that "the Stone Age did not terminate because there was a lack of stones", meaning that the hydrocarbon age will terminate not because of a lack of oil and gas resources, but because of the environmental problems linked to their massive use. We do not share this view and believe that the decline of world oil and gas productions will be largely linked to reserves depletion.

This question of carbon-energy resources constitutes one of the energy industry's most controversial issues, with pessimists and optimists engaged in bitter debate for the past 50 years or more (Figs. 2 and 3). As far back as the 1930s, analysts were predicting the imminent exhaustion of the world's oil reserves, while by 1999, articles in journals just as learned were asserting that to try to predict just when reserves would be depleted was to miss the point altogether. That very depletion, they argued, would generate its own cure: as reserves became scarcer, oil prices would rise, thus not only curbing demand but also triggering fresh efforts to transform existing resources into reserves. A number of points emerge from the debate.

To try to quantify fossil fuel reserves (resources are hydrocarbons known to be "down there", while reserves are hydrocarbons that the industry has the technical ability to produce profitably), whether in solid form (coal), liquid form (oil) or gaseous form (natural gas) is not irrelevant and does constitute a very real problem. The industry is largely unable
What people "can see": published information, i.e. proven reserves, which is an economical concept, which therefore changes with changes in technology and oil prices. These are the visible part of the iceberg

- What $99 \%$ of people "cannot see", i.e. the non-visible part of the iceberg, i.e. the already discovered resources in place on one hand, the ultimate reserves on the other hand

Discovered resources are not published, but could be estimated at $3000 \mathrm{Gbbl}$, i.e. three times the proven reserves of $1000 \mathrm{Gbbl}$

Ultimate reserves today (estimated 2000/3000 Gbbl) are two to three times the proven reserves of around $1000 \mathrm{Gbbl}$

Figure 2

The oil reserves question: Why is it so difficult to get a clear vision?
1919 "... The peak of US production will soon be past, possibly within three years..."

$1936 " .$. It is unsafe to rest in the assurance that plenty of petroleum will be found in the future merely because it has been in the past..."

1981 "... If petroleum is not there to begin with, all of the human ingenuity that can be mustered into the service of exploration cannot put it there..."

$1990 " . .$. Non-OPEC production in the longer term will at best remain stagnant and is more likely to fall gradually due to resource constraints..."

$1998 " .$. Global production of conventional oil will begin to decline sooner than most people think, probably within 10 years..."

Figure 3

Oil supply pessimism: a long story of inaccurate predictions [6]. 
to quantify finite stocks of "concentrated solar energy" (fossil biomass) when still at the resource stage, i.e. still "down there". This is particularly true in the case of solid-form energy such as coal, lignite, bituminous shales and gas hydrates.

On the other hand, the uncertainties involved in quantifying reserves of liquid (oil) and gaseous hydrocarbons are not nearly as great. Ultimate resources, i.e. the volumes "down there", can be assessed with much greater accuracy, probably with about $30 \%$ error in the case of oil and 50\% error in the case of gaseous (as opposed to hydrate form) gas (Tables 1-5 and Figs. 4-6).

In the case of so-called conventional reserves of oil and gas, the process of gradual reserve depletion and discovery of new deposits has been practically overshadowed in the last 20 or 30 years by three separate phenomena: the opening up of new zones to international investment for exploration and

TABLE 1

Observing the proven reserves gives an impression of growing abundance

\begin{tabular}{l|c|c|c|c}
\cline { 2 - 5 } & \multicolumn{2}{c|}{1973} & \multicolumn{2}{c}{2000} \\
\cline { 2 - 5 } & Gtoe & $\begin{array}{c}\text { Years } \\
\text { of consumption }\end{array}$ & Gtoe & $\begin{array}{c}\text { Years } \\
\text { of consumption }\end{array}$ \\
\hline $\begin{array}{l}\text { World oil } \\
\text { reserves }\end{array}$ & 86 & 30 & 140 & 40 \\
\hline $\begin{array}{l}\text { World gas } \\
\text { reserves }\end{array}$ & 52 & 48 & 140 & 65 \\
\hline
\end{tabular}

\section{TABLE 2}

Ultimate world oil conventional reserves: observing the "non-visible part of the iceberg" gives a different view

\begin{tabular}{l|c|c}
\hline $\begin{array}{l}\text { Ultimate world oil } \\
\text { conventional reserves }\end{array}$ & 1973 & 2000 \\
\hline Gbbl & $2000-3000$ & $2000-3000$ \\
\hline
\end{tabular}

Between 1973 and 2000 there is practically no increase in ultimate conventional oil reserves estimates.

TABLE 3

Breakdown of USGS 2000 view for ultimate conventional oil reserves [8]

\begin{tabular}{l|c}
\hline Already produced & 800 \\
Proven conventional & 1000 \\
Remaining to be discovered & 725 \\
Future "reserve growth" & 610 \\
\hline & 3135 million of barrels \\
\hline
\end{tabular}

TABLE 4

Estimated recovery rate of ultra-heavy crude oil [3]

\begin{tabular}{l|c|c|c}
\cline { 2 - 4 } & $\begin{array}{c}\text { Estimated volume } \\
\text { in place }(\mathrm{Gbbl})\end{array}$ & $\begin{array}{c}1995 \text { estimated } \\
\text { reserves }(\mathrm{Gbbl})\end{array}$ & $\begin{array}{c}\text { 2030 estimated } \\
\text { reserves }(\mathrm{Gbbl})\end{array}$ \\
\hline Orinoco & 1200 & 100 & 300 \\
\hline Athabasca & 1700 & 100 & 300 \\
\hline
\end{tabular}

Extra-heavy crude and bitumens will represent the major portion of new "reserves".

TABLE 5

Conventional and non-conventional oil reserves (in Gbbl) [9]

\begin{tabular}{|c|c|c|c|}
\hline \multicolumn{4}{|l|}{ Conventional reserves } \\
\hline Initial recoverable & 1800 & to & 2500 \\
\hline Of which already produced & 800 & & 800 \\
\hline Remaining to be produced & 1000 & & 1700 \\
\hline \multicolumn{4}{|c|}{ Non-conventional reserves (economically recoverable at 2030 horizon) } \\
\hline Deep offshore (below $500 \mathrm{~m}$ water depth) and Arctic areas & 100 & & 100 \\
\hline Gas-to-liquid conversion & 100 & & 100 \\
\hline Ultra-heavy crude oil $\left(10^{\circ} \mathrm{API}\right)$, bitumen & 600 & & 600 \\
\hline \multicolumn{4}{|l|}{ (roughly 50/50 for Orinoco and Athabasca) } \\
\hline Overall reserves (remaining to be produced) & 1800 & to & 2500 \\
\hline
\end{tabular}

Not included because in a different category of development cost and mostly for after 2030:

- bitumens in Athabasca carbonates;

- oil shales;

- coal-to-liquid conversion. 


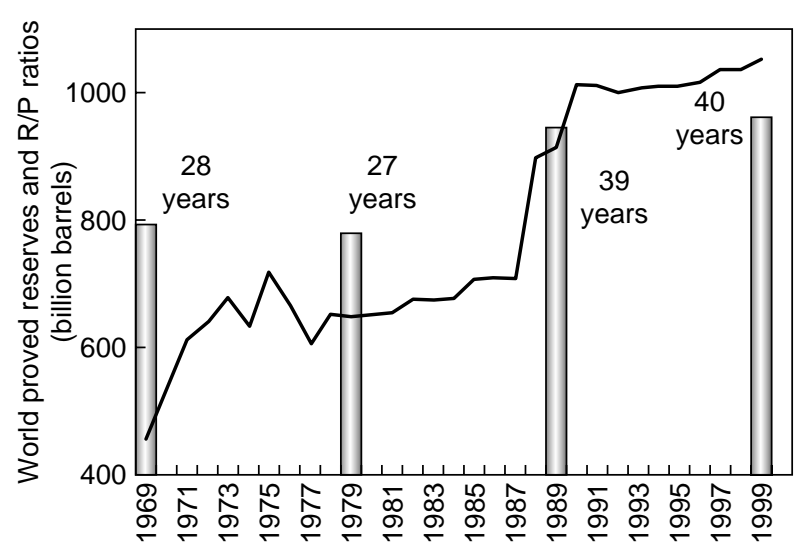

- More than 1000 billion barrels of proved reserves

- 500 to 1500 billion barrels of possible additional conventional resources

- 300 to 600 billion barrels of unconventional resources

Figure 4

Apparently abundant and growing oil reserves.

production; the gradual transformation of non-conventional resources (deep offshore oil, ultra-heavy crudes, etc.) into conventional reserves; and above all a major reassessment of the reserves contained in already-discovered deposits. This last phenomenon has itself masked two significant facts: firstly, estimates of ultimately recoverable reserves of socalled conventional oil have remained practically unchanged over the past 30 years; secondly, exploration programs were no longer managing to replace the volumes being consumed. This process of re-evaluation had two very closely related causes: oil in place (i.e. resources) was frequently underestimated when the deposits were initially discovered; and over time, technological progress led to improvements in the expected rate of recovery. If we take the US domestic oil industry as an example it is easy to see why, given the combination of all the factors described above, 30 years went by between the moment (at the end of the 1930s) when new discoveries were no longer large enough to offset the increase in consumption and the moment (in the early 1970s) when domestic production began to decline (Fig. 7). It seems reasonable to suppose that the same phenomenon will recur at world level.

If we take a longer-term view of the situation (i.e. the 2050 equation), the breakdown of energy resources by physical form (i.e. solids, liquids and gases) becomes less relevant because the industry now has the technological bridging tools to transform resources from one form to another. For example, both coal and oil residues can now be gasified, and liquid hydrocarbons can be produced from gas (e.g. conversion into oil products via Fischer-Tropsch-type processes or conversion of methanol into olefins). This

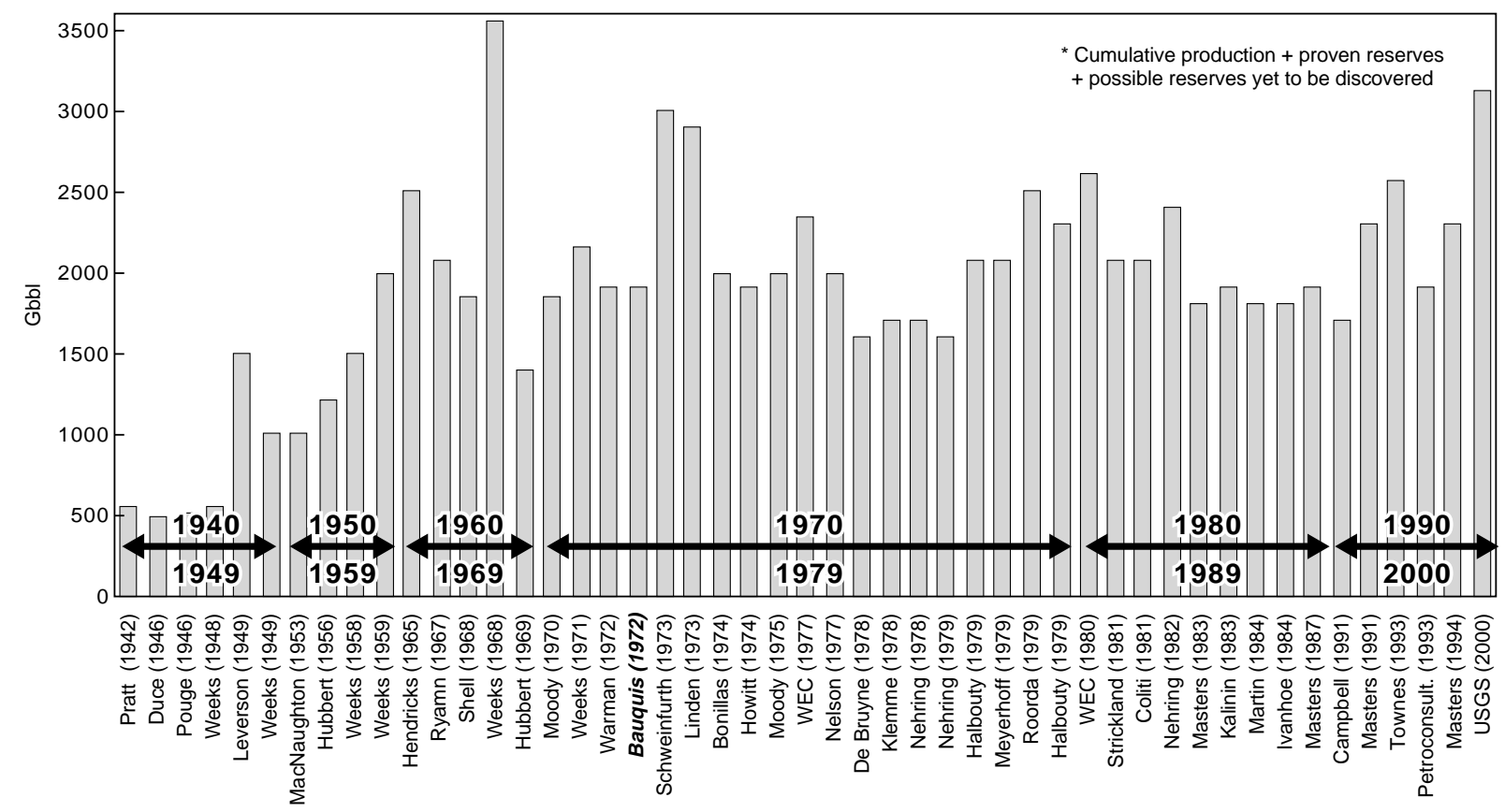

Figure 5

Evolution of ultimate conventional recoverable reserves estimates [7]. 
Increase in proven reserves from 1973 to 2000 largely due to old discoveries reevaluations and not essentially to new discoveries

- Reevaluations due both to increases in expected recovery rates, and to underestimation of accumulation volumes at early evaluation stages

- A secondary factor has been the acceleration of the delineationdevelopment process

- Last but not least the emergence of non-conventional reserves as part of new proven reserves (permanent blurring of frontiers between the two categories)

Figure 6

How to reconcile the diverging evolutions of "proven reserves" and "ultimate reserves"?

means that energy companies now have a continuum of fossil-fuel resources from which to develop production in whatever combination of energy forms the market requires. By the year 2050, this modular production base will be drawn upon in a variety of ways depending on the technical and economic parameters prevailing at the time. Well before the year 2050, one of the major economic parameters in the equation will be the need to preserve the environment. By 2010 or 2020 we could reach a consensus on the dangers of global warming, and in that case governments will have to take some form of action (eco-taxes, tradable emission permits, etc.) to ensure that those responsible for the release of carbon into the atmosphere themselves bear the cost, thus guaranteeing that the market regulates carbon emissions in a rational way. The implementation of a "polluter pays" system designed to control the release of carbon into the atmosphere-which is today seen as a probable development-would constitute a slight handicap to the future of coal gasification but it would represent a very serious setback for the gas-to-liquid conversion processes, whether they involve natural gas or gas produced by gasification of solid energy forms (coal, tars, biomass, etc.). On the other hand, the "costing" of carbon emissions would foster the development of an energy policy giving higher priority to hydrogen-based processes, which in turn would require the industry to come up with low-cost carbon dioxide sequestration technology.

As regards the conversion from resources to reserves, the most important factor is the distinction between oil resources and gas resources. When assessing production from an oil deposit, natural or "primary" recovery is fairly low, particularly in the case of heavy crudes. Primary oil recovery today, averaged out across all grades (i.e. heavy or light), is significantly less than $30 \%$. Recovery rates could be significantly improved in future with ongoing technological advances, particularly in the case of particularly dense or highly viscous resources. But the same is not true of gas, which does not involve marked qualitative differences. Except in marginal cases, where the reservoir shows very poor gas productivity, natural recovery rates for gas are usually quite high, i.e. around $70 \%$ to $80 \%$, leaving little or no room for enhancing recovery through technology.

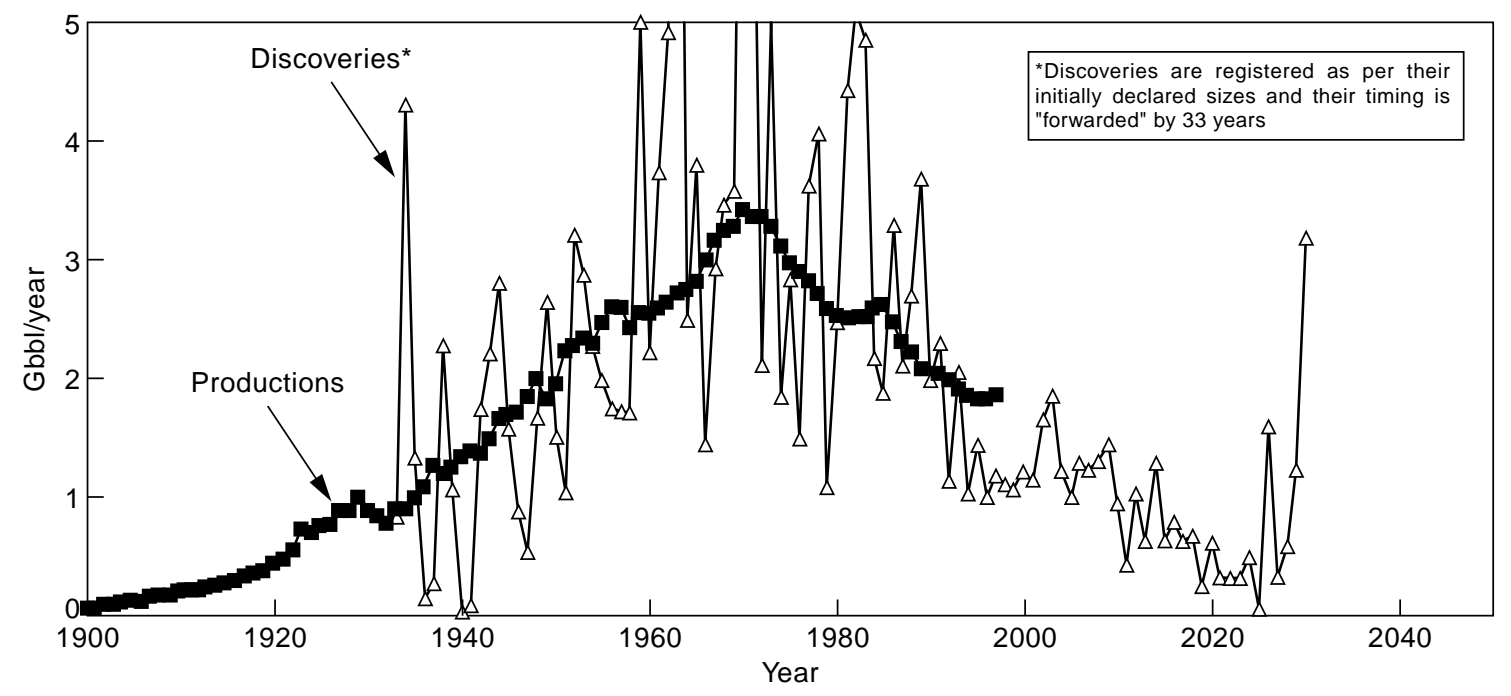

Figure 7

The irreversible decline of oil production in the USA [10]. 
Because of oil's low natural recovery rates, long-term forecasts, such as the 2050 equation being reassessed here, tend to understate oil reserves because they underestimate the "creation of new reserves" via improvement in recovery rate, particularly in the case of heavier grades of crude, as can be seen in the case of initial valorization of the ultra-heavy crudes and bitumens in Venezuela's Orinoco belt.

For the same reasons, forecasters risk making the opposite error in evaluating gas reserves. Except in a marginal way (fracturation combined with the use of horizontal drains in fairly impermeable reservoirs, for example), technology cannot create new reserves by boosting gas recovery rates. Gas exploration is not as far advanced as oil exploration, so the discovery of new fields is still boosting reserve statistics and could continue to do so for the 10 or even 20 years to come. On the other hand, once yearly consumption finally overtakes the volume of new reserves provided by exploration, the depletion of reserves will be rapid and inexorable, with no help from technological progress and little or no mitigation from any price rises triggered by rarefaction of supply.

Some mention should also be made here of the solid forms of oil and gas regarded by many industry analysts as "tomorrow's reserves". The key issue here is whether, by 2050 , energy companies will be in a position to transform resources such as oil shales and gas hydrates into reserves of oil and gas in significant quantity. For the purposes of this paper, a fairly conventional approach has been adopted in evaluating "solid" fossil fuel reserves, taking into account oil shales as "solids" but not bituminous sands or ultra-heavy crudes, even when these are in a "pasty" state or even solidified by reservoir conditions (this is the case with the bituminous sands in Canada's Athabasca deposits). This distinction is justified because there is a significant difference between bituminous sands and oil shales. The former are true crudes that have migrated and been made heavier by oxidation and biodegradation, while the latter are in reality a form of kerogen or "source rock", whose organic matter was not completely transformed into oil so that the process of expulsion and migration was not accomplished.

To what extent will schists and hydrate resources add to the reserves available by 2050 ? By that date, both these resources will probably still be considered as "tomorrow's reserves", as they have been for the past decades.

\section{THE OUTLOOK FOR RENEWABLE ENERGIES}

Most renewable energies are not new, it is just that the late 20th century rediscovered them thanks to new technologies. We are still in the early phases of development in this area, which makes it hard to evaluate accurately the contribution these energy sources are likely to make over the next 50 years.
In this early stage of rediscovery, some renewables (solar photovoltaic systems, wind energy and biofuels) are posting very high growth rates, sometimes of $20 \%$ to $30 \%$ per year, but this start-up growth is unlikely to last and it would be misleading to extrapolate this rate of development over the longer term.

One of the more important questions that needs to be answered regarding the future of renewable energies concerns the most suitable type of aid to speed up their development. In considering this question, we should remember that at any given time, scientific knowledge advances at a pace determined by its own needs at that development stage.

More research certainly needs to be done on renewable energies today and in future. But in order to be effective, this research should be decentralized and the funding must trickle down to a large number of small teams. Efficiency is not served by "throwing money" at large ventures or mega-programs in renewables research. Indeed, in the short term, rather than funding programs proposed by research laboratories and private enterprises, the money would be better spent in subsidizing the price of renewable energies offered to the market. This is just the opposite of the approach that was required for research on nuclear energy, which required large sums and centralized research and development.

What is needed to encourage development of renewable sources is a system of "eco-certificates", green pricing, or similar means to make electricity produced by renewable systems (or selected renewables if the aid is to be restrictively targeted) more economically or socially attractive to the consumer.

Details of the outlook for the different types of renewable energy have been amply covered elsewhere. It will suffice here, in conclusion, to sum up the expected 2050 breakdown of all renewable energies used for power generation and to compare those projections to figures from the most recent "state of play" drawn up in 1995 (Table 6). As it stands, Table 6 includes more than four fifths of the renewable energies likely to be consumed by 2050 . This forecast is the author's personal prediction. For reasons of space, the bases for that forecast are not detailed here.

The conclusion to be drawn from these comparative tables (Tables 6 and 7) is that by 2050, renewable energies (excepting major hydro-electric schemes) will still only be playing an accessory role in contributing to energy supply. Even with major subsidies, it is clear that between 1995 and 2050 the share of renewable energies in world energy production will actually decrease rather than grow markedly as many other forecasters assume.

This does not mean that governments should abandon their support for renewables development. That support should most definitely continue. But it should not be assumed that renewables could offer a credible alternative to 
TABLE 6

Electric power from renewable sources in 1995 and in 2050 [11]

\begin{tabular}{l|c|c|c|c}
\cline { 2 - 4 } & \multicolumn{2}{c|}{ Power installed (MW) } & \multicolumn{2}{c}{ Electricity generated (TWh) } \\
\cline { 2 - 5 } & 1995 & 2050 & 1995 & 2050 \\
\hline Hydropower & 700000 & 1000000 & 2400 & 3000 \\
Wind power & 5000 & 200000 & 10 & 500 \\
Biomass (for electricity production) & 10000 & 100000 & 50 & 500 \\
Geothermal & 7000 & 20000 & 30 & 100 \\
Solar (photovoltaic) & 600 & 30000 & 1 & 100 \\
Solar (thermal) & & & 10 & 50 \\
\hline Total & 722600 & 1350000 & 2501 & 4250 \\
\hline
\end{tabular}

Energy equivalence used for electricity, nuclear power and renewables has been accounted as if they had been generated by conventional thermal power plants having an efficiency of $40 \%$ (as conventionally done by TotalFina).

TABLE 7

The relative importance of electric power from renewable sources in 1995 and in 2050

\begin{tabular}{|c|c|c|c|c|c|c|c|c|}
\hline & \multicolumn{4}{|c|}{ Electricity generated } & \multirow{2}{*}{\multicolumn{2}{|c|}{$\begin{array}{l}\text { ei in percentage of } \\
\text { electricity generated }\end{array}$}} & \multirow{2}{*}{\multicolumn{2}{|c|}{$\begin{array}{l}\text { ei in percentage of } \\
\text { overall energy consumption }\end{array}$}} \\
\hline & \multicolumn{2}{|c|}{ In TWh } & \multicolumn{2}{|c|}{ In Gtoe* } & & & & \\
\hline & 1995 & 2050 & 1995 & 2050 & 1995 & 2050 & 1995 & 2050 \\
\hline $\begin{array}{l}\text { Electricity consumption } \\
\text { (all origins) }\end{array}$ & 13000 & 42000 & 2.8 & 9.0 & $100 \%$ & $100 \%$ & $34.0 \%$ & $50.0 \%$ \\
\hline Hydropower** & 2400 & 3000 & 0.5 & 0.6 & $18.0 \%$ & $7.0 \%$ & $6.5 \%$ & $3.5 \%$ \\
\hline Other renewables & 100 & 1250 & 0.02 & 0.3 & $0.8 \%$ & $3.0 \%$ & $0.3 \%$ & $1.5 \%$ \\
\hline Total renewables & 2500 & 4250 & 0.52 & 0.9 & $18.8 \%$ & $10.0 \%$ & $6.8 \%$ & $5.0 \%$ \\
\hline
\end{tabular}

* Energy equivalence used for electricity, nuclear power and renewables has been accounted as if they had been generated by conventional thermal power plants having an efficiency of $40 \%$ (as conventionally done by TotalFina).

** From which over $95 \%$ of large hydropower plants (i.e. plants larger than $10 \mathrm{MW}$ ).

the other group of non-fossil energies: nuclear power. However, it is conceivable that renewable energies will develop more rapidly that suggested here (Table 7).

One trigger could be a significant breakthrough in genetic engineering, leading to a substantial improvement in the economics of biomass energy thanks to GMOs. Obviously, development of artificial chlorophyll synthesis could have an even greater impact.

\section{THE FUTURE FOR NUCLEAR ENERGIES}

In this discussion of nuclear power, both singular and plural will be used to describe the nuclear industry, and the reasons for the choice of plural in the chapter heading will become obvious by the conclusion. First of all, what is the current state of play? Nuclear power accounts for $18 \%$ of world power generation, i.e. $6 \%$ of all energy consumed, and more or less equivalent to the share of hydro-electric power.
Nuclear power plants in use in the world today are fairly homogeneous, being conventional fission reactors rather than the fast-breeder type. There are different types of processes in use, which do not concern us here; suffice to say that the great majority of nuclear plants involve pressurized water reactors (PWR). These plants use an enriched uranium cycle involving either conventional fuel (3.5\% uranium-235) or MOX fuel containing plutonium and uranium oxides. These processes are regarded as safe and reliable. There has been only one major accident involving a nuclear power plant so far-at Chernobyl in the ex-USSR - and this is considered by the industry as a "Soviet accident" rather than a "nuclear accident". However this very description points up the possible Achilles heel in nuclear power: the major risk is not so much of a technical breakdown or accident but an incident arising from human error or political context (terrorist attack, civil strife, war, etc.). It is possible to evaluate the risk for a nuclear power station operating under "normal" conditions 
(technical incidents are commonly measured in terms of likely fatalities), and truly technical risk has now been brought down to a level lower than that involved in the operations of any other major industrial activity_and of course far lower than the risk involved in smoking, driving a car or working as a carpenter or a roofer.

Another objection frequently voiced concerning the nuclear sector involves fears about final-phase waste disposal: What is to be done with spent but still radioactive fuel (whether reprocessed or not)? Where and how is waste to be stored? How are power stations and other facilities to be dismantled when no longer needed? Nuclear power companies obviously still have a lot to learn about communication, because the industry already has or soon will have the means to solve these problems, using either techniques already developed or processes that are reasonably likely to be ready for use by the time they are needed, and at a cost that will not significantly raise the cost of nuclear-generated electricity.

The third major question hanging over the nuclear industry concerns supplies of fissionable material or fuel. Given the cycles currently in use this means reserves of uranium. Fortunately, it is possible to lower quite markedly the minimum acceptable richness of the ore being used (if necessary, even seawater could eventually be used as a source of uranium) without greatly increasing the unit cost per $\mathrm{kWh}$ generated, because nuclear fuel cost is only a minor element in the cost breakdown of nuclear electricity.

Furthermore, should nuclear fuel resources in fact become so depleted as to raise the cost of the $\mathrm{kWh}$, within 15 or 20 years the industry could restart fast-breeder programs. Fast-breeder reactors produce a much greater quantity (30 to 40 times more) of electricity from the same amount of uranium. Indeed, it was something of a surprise when the most advanced prototype in the world, France's Superphénix, was finally shut down. Given that reserves of uranium could run short by 2050 and that fast-breeders should contribute to solving the problem of disposing of spent fuel, the government's shut-down decision does not seem rational. On the contrary, with no firm data yet on the greenhouse effect, the precaution principle would seem to dictate that such a power plant remain in operation for as long as possible, producing at the maximum capacity considered safe by the relevant authorities. In that way, power producers would have benefited from 30 or 40 years of fast-breeder operation at industrial level, gaining knowledge of operating and maintenance costs, equipment aging problems and reliability, etc. Such experience would have been invaluable, more than justifying the long-term operation of the plant, even in the unlikely event that the actual operations resulted in a marginal net loss in financial terms.

And of course any evaluation of the long-term prospects for nuclear power must include all potential nuclear cycles, not just those currently operating in industrial mode. To start with, by 2010 or 2020 , there will be a demand for reliable and easy-to-operate, small-capacity (100 to $500 \mathrm{MW}$ ) nuclear power stations, especially in emerging economies. The hightemperature, helium-cooled cycle (HTR) should be well suited for this purpose. Other cycles could also be used to reduce even further the risk of overheating and core meltdown. With this in mind, Nobel Prize-winning physicist Carlo Rubbia has proposed using so-called "spallation" reactors that involve an external flow of particles which would be stopped automatically as soon as any function of the reactor went outside normal operating parameters [12]. In the much longer term we could see fusion reactors. There is some debate about whether the solution here is "hot" or "cold" fusion, but in the long run some form of fusion is likely to add to the available nuclear options. This is why it is more accurate to refer to nuclear energies in the plural rather than the singular.

In conclusion, it is quite unrealistic to consider nuclear power as an accident of history and doomed to extinction: nuclear energies will be making a comeback well before 2050 .

\section{THE WORLD ENERGY EQUATION IN 2050}

The approach used in this concluding assessment will be the following: firstly an evaluation of production levels of the various fossil fuels, factoring in reserves and likely production costs. Correlation against energy needs will then be used to determine the quantities of non-carbon energies required by 2050 .

Firstly, let us consider 2050 production volumes of fossil energies. As regards coal, the production constraints involve the amount of available reserves, or volumes economically producible (as opposed to resources, or volumes simply "down there") and acceptable levels of carbon dioxide emissions. Not to mention sulfur, methane, dust particles and ash, which will go beyond local pollution to become a regional and global issue as well. Future coal-fired power plants will be able to filter out most solid particle emissions, particularly if gasification processes are used, but little can be done about particles going up the millions of household chimneys. The same is true for sulfur emissions. And all coal deposits contain quantities of coal bed methane which are released directly into the atmosphere during mining operations (whether open pit or underground mines).

Given the high costs involved in coal logistics (transport costs per energy unit are even higher than those for gas), a large part of the planet's coal resources will still not be counted as reserves by 2050 , even despite the potential for clean conversion of coal into electricity (with or without gasification) at the pit head. Furthermore (and this may well be the most important factor here), available data on reserves suggests a certain confusion and that some resources may be 
counted incorrectly as actual reserves. It is high time that the coal industry worldwide made the effort to apply the same (or at least similar) distinction as oil and gas companies, which release very few figures on resources but detailed data on reserves.

Without going into details here, the above factors suggest that by 2050 world production of coal and lignite could rise from the present level of $4.8 \mathrm{Gt}$ (i.e. $2.2 \mathrm{Gtoe} / \mathrm{y}$ ) to somewhere between 8 and $10 \mathrm{Gt}$ (4-5 Gtoe/y). These figures suppose (and this is the weak link in the hypothesis) that restrictions on release of $\mathrm{CO}_{2}$ into the atmosphere will not have a major impact on production. This assertion assumes that humankind will, in the end, accept a much greater global warming risk than seems reasonably acceptable to us today.

As regards oil consumption, a slowdown due to the depletion of reserves will be felt quite rapidly, say between 2010 and 2020. By that stage, it will be clear to most analysts that new discoveries are no longer able to cover the volumes lost to consumption, and that the statistical increase in reserves and consumption is mainly due to two factors: an increase in reserves within conventional deposits already discovered, and the increasing conversion of nonconventional resources into conventional reserves (this will mainly involve extra-heavy crudes and bitumens, which should supply between 500 and 1000 billion barrels of new reserves by 2050 , and the deep and ultra-deep offshore which will supply between 100 and 200 billion barrels of additional reserves). Added awareness of this situation should slow the physical rarefaction of reserves by triggering price rises that should put a brake on consumption. It seems probable that the present world output of 3.7 Gtoe will rise not much more than about $30 \%$ to peak at 5 Gtoe between 2010 and 2020 before falling back fairly rapidly to about 4.5 Gtoe by 2030 . By 2050, overall production should have fallen back to a level close to current output, i.e. 3.5 Gtoe, plus the relatively marginal volumes of liquid hydrocarbons produced by gasto-liquid conversion of natural gas or synthetic gas derived from coal, biomass or waste. This scenario fits currently available data concerning not only proven oil reserves but ultimate resources and reserves.

In the case of natural gas, our lack of accurate knowledge of the quantities "down there" or ultimate resources makes prediction more hazardous. But here, again, the question of reserves will come to the fore once the industry realizes that new discoveries are no longer going to be able to replace consumed reserves. The present vision is one of very abundant reserves, and this optimism could last until 20102020. But once reality dawns, the awakening is likely to be ruder than in the case of oil because with gas there is less scope for re-evaluating the reserves in deposits already discovered. Of the two factors at work with oil reservesunderestimation (or understatement) on initial evaluation, and technical improvement of the recovery rate-only the former can help in the case of gas. But even just this factor can make quite a difference: consider the case of the Groningen gas field, which has seen its reserves triple in the space of 30 years. On the other hand, with some fields there is no progress at all: the real reserves on Frigg and Lacq, easy to quantify because the fields are now depleted (or nearly so), were pretty much identical to the estimates announced during the first years of production. This leads us to a major question: Are the gas deposits at Urengoï, the Yamal peninsula and North Dome-South Pars going to turn out like Groningen or like Frigg? Even before 2010 it will probably be clear that initial estimates were fairly accurate and that there is little scope for re-evaluation. The second major question concerning gas reserves is whether, during the next 20 or 30 years, gas exploration programs are going to yield 50 or so new gas provinces equivalent to the one in southern Bolivia, or no more than a dozen. The second figure appears more likely.

Another factor likely to reduce the level at which world gas output peaks is the lack of physical flexibility in gas chains and the major investments required to set them up. In practice, no major new gas pipelines or liquefaction plants are going to be built unless this infrastructure is guaranteed a profitable working life averaging 30 years. The peak, or at least the plateau of maximum gas production (which could last 30 or 40 years) should begin about 2015-2025 and last until 2050-2060. Then world gas output will begin to decline. This decline could be delayed if exploration of the deep horizons of sedimentary basins turns up some unexpectedly major gas reserves or if technological breakthroughs have by that time enabled the industry to convert hydrate resources into gas reserves. Both are possible but fairly improbable.

Production volumes at the plateau stage are likely to be a little more than double present output, i.e. about $4.5 \mathrm{Gtoe} / \mathrm{y}$. So, factoring in the estimates outlined above, overall fossil energy production by 2050 can be broken down as follows: coal 4.5 Gtoe, oil 3.5 Gtoe and gas 4.5 Gtoe, giving total fossil-fuel output of 12.5 Gtoe. But according to most demand scenarios, overall energy needs will amount to between 25 and $30 \mathrm{Gtoe}$, and according to the more modest scenario outlined above (assuming world population of 8 bn $+/-2$ bn rather than 10 bn $+/-1$ bn) overall demand will be about 18 Gtoe-which is still double the present consumption of 9 Gtoe. Even if we accept this latter "modest" scenario, the energy shortfall to be made up by non-carbon energies is still a very significant 5.5 Gtoe by 2050 .

If, as estimated above, renewable energies can only contribute between 1 and 1.5 Gtoe, then by 2050 nuclear fission will be called upon to make up the very considerable shortfall of between 4 and 4.5 Gtoe. These conclusions are summed up in the following summary table (Table 8).

In order to facilitate the memorization of these conclusions we have given a graphic representation of world primary energy resources for the past (Fig. 8) and for the past 
TABLE 8

A vision of medium- and long-term world energy balances [11]

\begin{tabular}{|c|c|c|c|c|c|c|}
\hline & \multicolumn{2}{|c|}{2000} & \multicolumn{2}{|c|}{2020} & \multicolumn{2}{|c|}{2050} \\
\hline & Gtoe & $\%$ & Gtoe & $\%$ & Gtoe & $\%$ \\
\hline Oil & 3.7 & 40 & 5.0 & 40 & 3.5 & 20 \\
\hline Natural gas & 2.1 & 22 & 4.0 & 27 & 4.5 & 25 \\
\hline Coal (including lignite) & 2.2 & 24 & 3.0 & 20 & 4.5 & 25 \\
\hline Total fossil fuels & 8.0 & 86 & 12.0 & 87 & 12.5 & 70 \\
\hline Renewables & 0.7 & 7.5 & 1.0 & 6.5 & 1.5 & 8 \\
\hline Of which used for electricity generation & 0.5 & & 0.7 & & 0.9 & \\
\hline Nuclear & 0.6 & 6.5 & 1.0 & 6.5 & 4.0 & 22 \\
\hline Total commercial energies & 9.3 & 100.0 & 14.0 & 100.0 & 18.0 & 100.0 \\
\hline
\end{tabular}

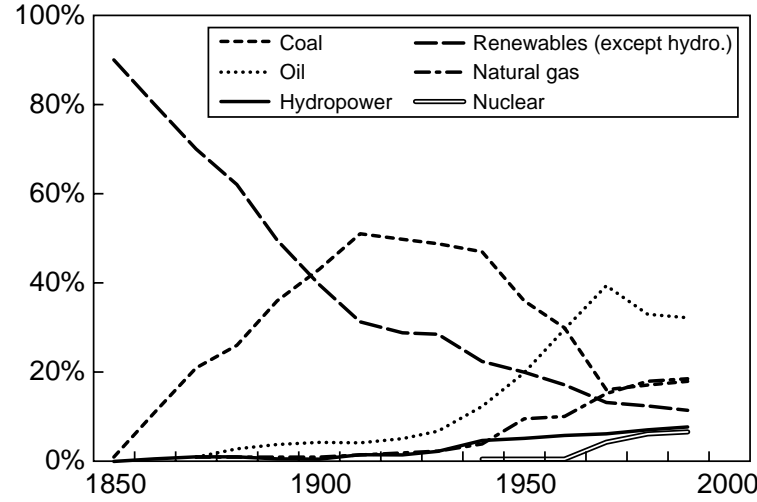

Figure 8

World primary energy sources: 1850-1990.

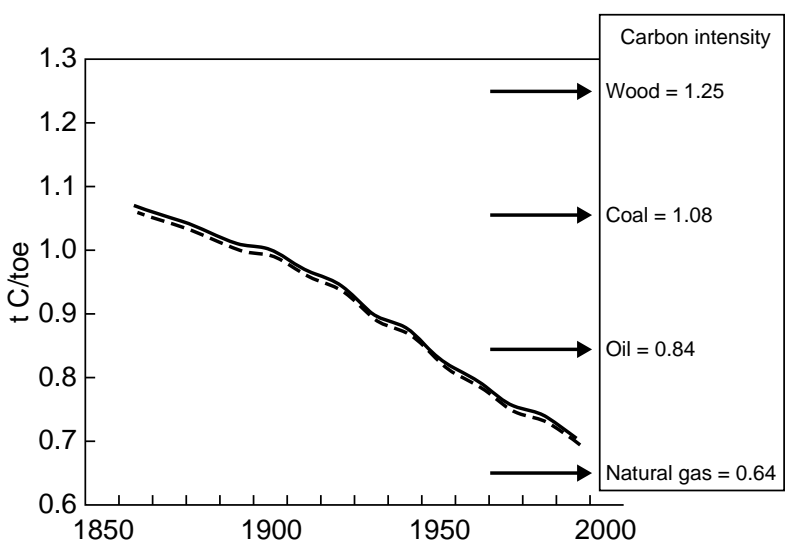

Figure 10

Carbon intensity from the various energy sources [13].

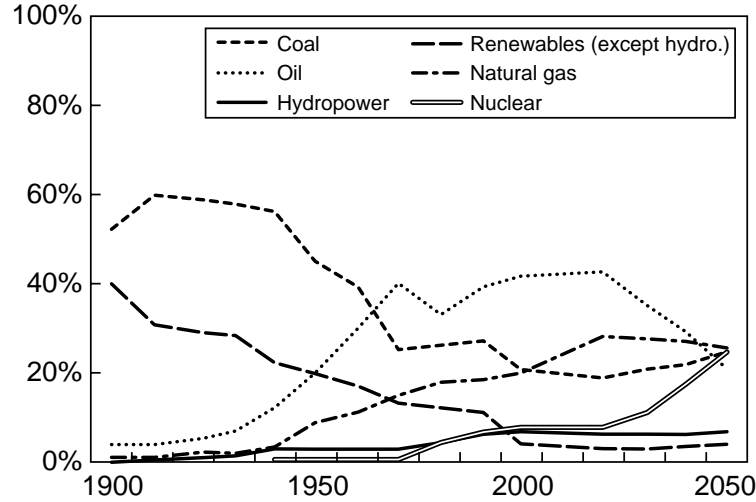

Figure 9

World primary energy sources: 1900-2050.

and the future (Fig. 9).While the questions related to climate change are not a central issue in the present paper, we have nevertheless illustrated the question of changes in carbon intensity (Fig. 10) and the important issue of likely $\mathrm{CO}_{2}$ content of our atmosphere up to year 2050 (Fig. 11). This figure is obviously based or our own energy mix scenario and therefore reflects the "vision" of Table 8.

\section{EPILOG}

A number of major questions concerning future developments in the energy industry in the short and medium term have been deliberately omitted from the assessment presented here.

No mention has been made of geopolitics, the geographic concentration of reserves, mergers and acquisitions, or of 


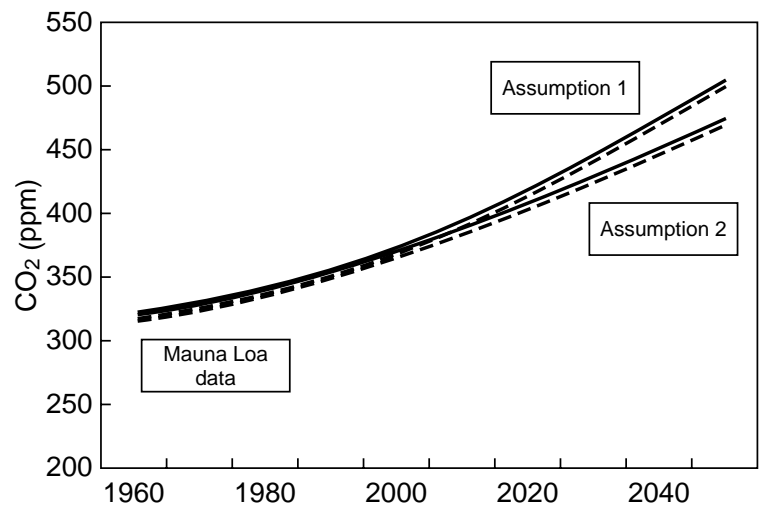

Assumption 1: use of $1 \mathrm{Gt} C$ generates an increase of $0.277 \mathrm{ppm}$ $\mathrm{CO}_{2}$ in the atmosphere

Assumption 2: use of $1 \mathrm{Gt} C$ generates an increase of $0.228 \mathrm{ppm}$ $\mathrm{CO}_{2}$ in the atmosphere

Figure 11

Estimated evolution of $\mathrm{CO}_{2}$ emissions under Table 8 scenario.

moves to diversify by oil, gas and power companies. On the technical level, no mention has been made of the complex question of carbon sequestration-whether biological (forests, etc.), chemical or physical (injection, etc.) —or of the "de-carbonization" of hydrocarbons, oxygen-fired power plants (which avoid dilution of $\mathrm{CO}_{2}$ by nitrogen in the air) or of a number of other similar subjects. This is because, despite their obvious interest, all these issues are relatively marginal to an assessment of the likely global energy mix by 2050 .

Nor has there been any discussion of the competition between centralized power generation (major hydro-schemes, large coal-, gas- or nuclear-fired power plants) and decentralized systems (renewable energies, fuel cells, smallscale co-generation, micro-turbines or even micronuclear plants). This is because these issues have no vital bearing on the 2050 energy mix either. This point of view may seem surprising, but it must not be forgotten that technologies such as micro-turbines and probably also fixed fuel cells will consume mainly natural gas, while fuel cells used to power motor vehicles will probably generate their hydrogen fuel from liquid hydrocarbons or related liquid energy chemicals. We must not forget that producing the amounts of hydrogen required will generate quantities of carbon dioxide more or less similar to those involved when using advanced combustion engines, as the most likely hydrogen production process will be reforming (or some other chemical conversion) either of liquid oil products or of liquid chemical derivatives if the conversion is carried out on board the vehicle. If the conversion is performed upstream from the vehicle, such as at a hydrogen-filling station, natural gas would be the most likely feedstock. If the process were carried out even further upstream, in large hydrogengeneration plants, the feedstock could be anyone of crude oil, gas, coal or biomass. In such case the aim of using large hydrogen plants would probably be to have the possibility to "sequester" the carbon dioxide (re-injection, etc.) to prevent it being released into the atmosphere.

Only widespread panic about the consequences (real or supposed) of the greenhouse effect, and a very high cost of sequestering carbon dioxide could justify in the near future (say before 2020) the costs involved in the other hydrogengeneration option, which is nuclear (either by electrolysis or thermal process). Should environmental concern reach catastrophic proportions-which seems quite unlikelydemand for non-carbon-generated electricity and hydrogen (i.e. essentially provided by nuclear power) would skyrocket. At that stage there would be much lamenting over the 20 or 30 years of fast-breeder cycle feedback experience lost in the case of France by the politically-motivated closure of the Superphénix breeder reactor.

In the final analysis, there are two essential factors, linked to the future long-term energy mix, that should be highlighted here.

The first concerns the level of carbon dioxide in the atmosphere over the coming decades and its potential impact in terms of climate change. The consequences in terms of $\mathrm{CO}_{2}$ levels in the atmosphere of the 2050 energy mix hypothesis advanced here have been set out in graph form (Fig. 11). As can be seen, $\mathrm{CO}_{2}$ levels, which have already risen from 280 to $360 \mathrm{ppm}$ in less than 200 years, will continue to rise, reaching some $500 \mathrm{ppm}$ (i.e. somewhere between 450 and $550 \mathrm{ppm}$ ) by 2050 .

This situation appears to be almost inevitable, regardless of any new policies that may be introduced over the next 20 years, largely because of the "inertia effect" of existing energy systems (i.e. the huge investment in existing infrastructures both for energy production and for energy consumption). Given that atmospheric $\mathrm{CO}_{2}$ levels never rose above 300 ppm over the preceding 400000 years, a period which experienced very major climate changes, we can only guess at the potential impact on climate of levels around 500 ppm: in spite of all the advances in mathematical climate modeling, there are still large uncertainties. But whether the consequences are minor, major or even catastrophic (unlikely, but not totally impossible), we are going to have to live with them.

The second important factor emerging from the future energy mix will be the increasing complementarity or synergies in the long term, between fossil fuels and nuclear power (Figs. 12 and 13). This complementarity is already evident today in the respective uses of these two families of energy resources (Fig. 12). It is worth remembering that liquid hydrocarbons are naturally best suited to three different types of uses:

- as a raw material (petrochemicals, chemicals, solvents, lubricants, bitumens, etc.);

- as a transportation fuel (land, sea or air), because of their high energy content per unit of volume; 


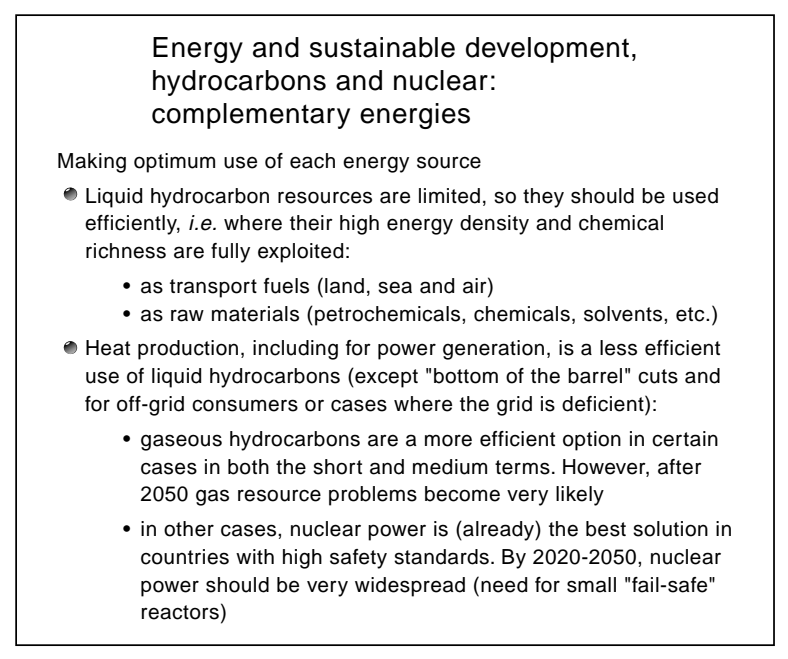

Figure 12

Energy and sustainable development hydrocarbons and nuclear energy: complementary already today.

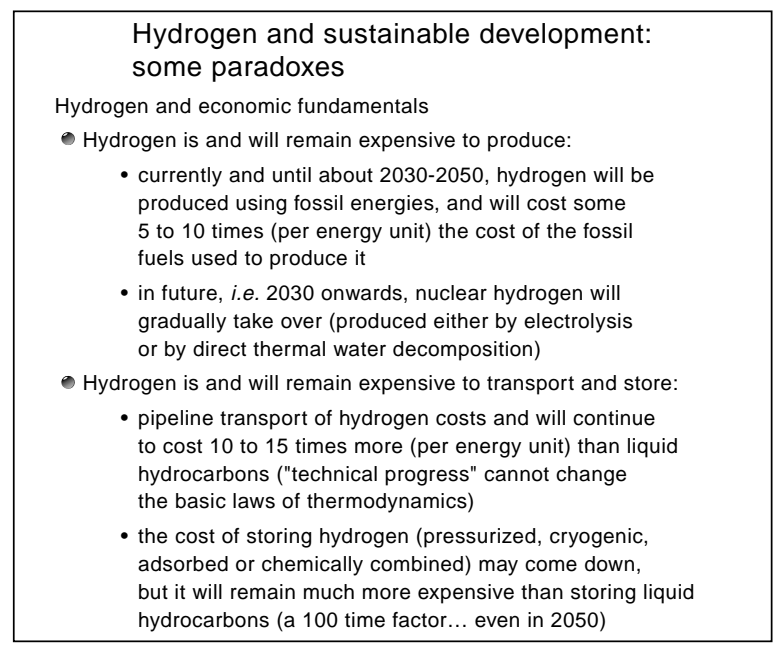

Figure 14

Hydrogen and sustainable development: economic fundamentals

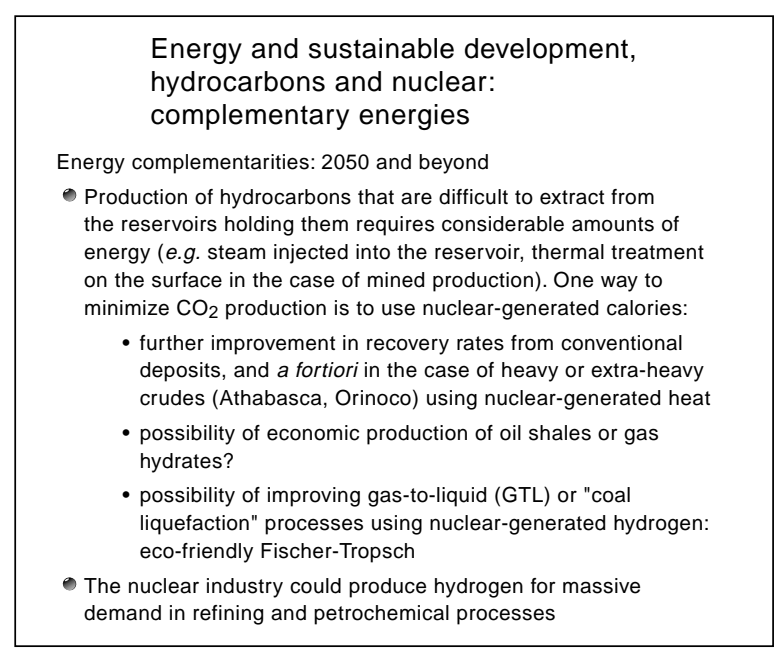

Figure 13

Energy and sustainable development hydrocarbons and nuclear energy: even more complementary energies tomorrow.

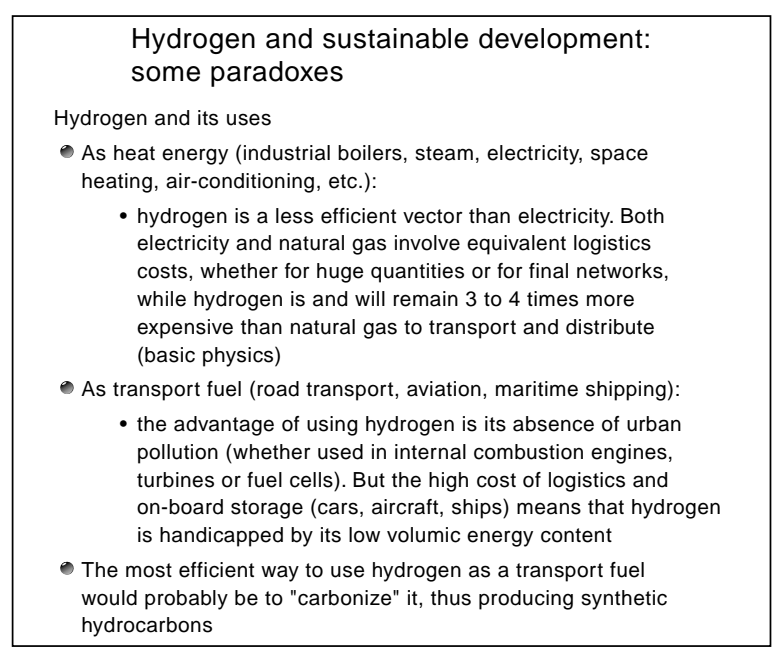

Figure 15

Hydrogen and sustainable development: How to best use hydrogen?
- as the means to provide energy (thermal or electrical) in off-grid situations (isolated factories, farms, plantations, villages, etc.) where energy demand is relatively heavy. The low cost of transporting liquid hydrocarbons makes this the logical solution in such situations. In very low energy-demand situations involving isolated off-grid customers, renewable energies, and above all photovoltaic solar systems, should prevail.

Unlike hydrocarbons the role of nuclear energy today, and for the next 20 or 30 years, is limited to power generation in situations where demand is both heavy and geographically concentrated. Therefore, because of their different characteristics, nuclear and fossil fuels are already today much more complementary energies rather than competing ones.

Closer to 2050, synergies between fossil fuels and nuclear power should increase. In such a time horizon, it will be necessary to improve further and further the recovery rate from oil deposits, particularly deposits of heavy and extraheavy crude. It may even be necessary to resort to producing oil shales, a process that was rather widely used in the early 20th century (an attempt in the US to restart this industry after the first oil shock was a clear failure). To achieve these 
objectives while at the same time minimizing emissions of $\mathrm{CO}_{2}$, the oil industry will have to use non-fossil heat energy. This in turn means that the required energy, one way or another, could well be provided by nuclear reactors.

The same reasoning should apply to gas-to-liquid (GTL) processes, because their high energy consumption (today's processes consume between $35 \%$ and $45 \%$ of their input energy) means they would be uneconomical if financial penalties on $\mathrm{CO}_{2}$ emissions were imposed. Here, again, nuclear energy should provide a convenient solution by providing heat for these processes, ensuring that liquid hydrocarbon resources would remain available longer than presently expected.

Further synergies between hydrocarbons and nuclearproduced hydrogen systems ${ }^{1}$ should develop as soon as nuclear hydrogen becomes competitive on a full-cost basis (i.e. costs where external costs such as those linked to $\mathrm{CO}_{2}$ emissions are factored in). At that stage, nuclear hydrogen could be used by major refining and petrochemical complexes both for upgrading heavy and extra-heavy crude and for lightening or advanced purification of various oil products or petrochemicals. However even if by 2050 we can expect the nuclear industry to be able to supply large quantities of hydrogen at a reasonable cost, hydrogen-based energy systems will remain uneconomical or inefficient for the fundamental reasons already outlined above (Fig. 14). Fortunately there may well be other ways in which nuclear hydrogen can be used to extend the resource base of the oil industry. In fact, the best way to make hydrogen more energy-compact would be to add carbon, thus creating synthetic hydrocarbons in an eco-friendly version of the Fischer-Tropsch process! This statement may seem rather paradoxical, especially in the light of current energy thinking, where decarbonization is commonly regarded as a cure for all evils (Fig. 15).

In conclusion, even if concern about global warming does not trigger major changes in the world's preferred energy sources by the year 2050 - and this is the supposition that underlies the above forecast (as it provides for a relatively strong increase in coal use to meet the shortfall in overall energy supply) — by the year 2020 we should be seeing the start of a major change in the energy mix.

(1) Japan has already developed an experimental HTTR nuclear reactor designed to produce hydrogen. This $30 \mathrm{MW}$ reactor was started up in 1998 but experienced some problems and was shut down. It apparently started operating again in 2000.
Until 2020 there will be a strong growth in the use of hydrocarbons (oil and particularly gas), while from 2030 onwards much of the additional energy demand will have to be met by nuclear power. We should therefore face these rather inevitable facts and prepare for a largely nuclear longterm future-or more precisely for a world where fossil fuels and nuclear fission will become synergetic energy sources ensuring a sustainable energy future.

\section{ACKNOWLEDGMENTS}

The author wishes to acknowledge the helpful comments and suggestions made by Paul Alba, Denis Babusiaux, Emmanuelle Bauquis, Jean-Claude Boudry, Georges Dupont-Roc, Jacques Foos and Roland Geoffrois.

\section{REFERENCES}

1 Bauquis, P.R., Brasseur, R. and Masseron, J. (1972) Les réserves de pétrole et les perspectives de production à moyen et long terme. Revue de l'Institut français du pétrole, 27, 4, 631658.

2 Bauquis, P.R. (1998) L'effet de serre et les réserves énergétiques. Énergies, 35, 11-12.

3 Bauquis, P.R. (1998) What Future for Extra-Heavy Oil and Bitumen: the Orinoco Case. 17th Congress of the World Energy Council, Houston, USA, September.

4 Bauquis, P.R. (1998) Défis techniques et enjeux économiques des huiles extra lourdes. Pétrole et Techniques, 417, 54-62.

5 Bauquis, P.R. (1999) Les bruts ultra lourds de l'Orénoque et de l'Athabasca. Ingénieurs Géologues, 74, 4-9.

6 Butler, D. ( 2001) US EIA/DOE AEO 2001 Conference.

7 IFP/DSEP, adapted from Martin (1985) and Campbell (1992) -Updated 2000.

8 USGS (2000) CD Rom, World Petroleum Congress, Calgary, Canada.

9 Bauquis, P.R. (2000) Constraints on Fossil Fuels Supplies for the Next Half Century, Fort Lauderdale, 28 November 2000.

10 Alba, P. and Bourdaire, J.M. (2000) Revue de l'Énergie, May, 516, 209-217.

11 Bauquis, P.R. (1999) Un point de vue sur les besoins et les approvisionnements en énergie à l'horizon 2050. Revue de l'Energie, 50 ans, September, 509, 503-510.

12 Rubbia, C. (1998) Nucléaire : une voie nouvelle. Énergies, 35 , 18-19.

13 Nakicenovic, Grübler and MacDonald (1998) Global Energy Perspectives, Cambridge University Press.

Final manuscript received in June 2001 